\title{
THREE NEW GESNERIACEAE FROM PALAWAN, PHILIPPINES
}

\author{
M. Mendum*
}

\begin{abstract}
Two new species of Aeschynanthus and one new Henckelia are described and illustrated. Trichosporum grandiflorum Elmer (non D. Don) is transferred to Aeschynanthus and renamed A. elmeri Mendum.
\end{abstract}

Keywords. Aeschynanthus, Gesneriaceae, Henckelia, new combination, new species, Palawan.

\section{INTRODUCTION}

The Philippine island of Palawan has a strong floristic relationship with Borneo (Merrill, 1923b; Atkins et al., 2001). Aeschynanthus sect. Aeschynanthus, to which the two species described belong, appears to have its centre of development in Borneo; the genus Henckelia has about 50 species in Borneo (Weber \& Burtt, 1997) but hitherto only one, also from Palawan, was known from the Philippines. The new species were collected during a Royal Botanic Garden Edinburgh/Philippine National Herbarium expedition to Palawan in 1998, which proved very rich in Gesneriaceae; the Cyrtandra species are described by Atkins \& Cronk (2001).

Aeschynanthus (sect. Aeschynanthus) curvicalyx Mendum, sp. nov. Fig. 1A-E. Calyx brevis crateriformis huius speciei novae eam ab speciebus ceteris Aeschynanthi sect. Aeschynanthi corollas magnas clare rubras ad basin gibbosas sed calyces tubulosos habentibus distinguit.

Type: Specimen cult. RBGE accession no. 19981826, originating from Philippines, Palawan, on path from Camp 3 towards Cleopatra's Needle, just above bamboo thicket, epiphyte closely appressed to tree trunk, (living material [seed] only), alt. 1500m; 22 i 1998, Mendum, Argent, Cronk, Middleton, Wilkie, Fuentes \& Chavez 25434 (holo. $\mathrm{PNH}$, iso. E).

Epiphyte. Stems climbing and rooting from most nodes then becoming pendulous and flexuous, to $\mathrm{c} .150 \mathrm{~cm}$, bright green sometimes flushed reddish, with sparse patent white mostly eglandular hairs to c. $0.5 \mathrm{~mm}$, becoming scattered on older stems; internodes to $4 \times 0.3 \mathrm{~cm}$. Leaves opposite, thick and succulent, glossy mid-green above and paler below, minutely white hairy on margins; blade $2.3-5.0 \times 1.1-2.7 \mathrm{~cm}$, broadly lanceolate to ovate, margins entire, apex acute or rarely rounded, tip blunt, base rounded, mid-vein impressed above and prominent below, other veins indistinct; petioles 6-9mm, sparsely white hairy. Inflorescences borne on pendulous stems,

\footnotetext{
* Royal Botanic Garden Edinburgh, 20A Inverleith Row, Edinburgh EH3 5LR, UK.
} 
axillary or pseudoterminal, 2-4-flowered. Peduncles (3-)8-20mm, sparsely white hairy, sometimes borne on short spurs. Bracts 1-3mm, oval, white hairy. Bracteoles $1.5-6 \mathrm{~mm}$, broadly elliptic, sparsely white hairy. Pedicel green, $14-16 \mathrm{~mm}$, slender, abruptly widening at apex, with scattered minute eglandular hairs. Calyx 5-8mm, bowl-shaped with shallow incurving lobes and with abscission layer at base, pale greenish-white flushed reddish in apical half, externally with occasional minute eglandular hairs towards apex. Corolla tubular, arcuate, $5.2-5.7 \mathrm{~cm}$, with small asymmetric gibbosity at base then flaring gently to throat, lobes spreading; externally bright scarlet, pale at base, internally cream at base of lobes and in throat and tube, with a red central line on each of the three lower lobes, upper lobes c. $9 \times 4 \mathrm{~mm}$ (central sinus $3 \mathrm{~mm}$ ), lateral and lower lobes c. $9 \times 9 \mathrm{~mm}$, all rounded triangular and fringed with tiny glandular hairs; externally with sparse $0.3 \mathrm{~mm}$ red glandular hairs on tube, internally with thickened papillate areas where lobes fuse and with short papillae in throat and nectar-containing tube. Stamens 4 , inserted about $3 / 4$ up tube and slightly exserted; filaments cream, purple-flushed apically, papillose, posticous pair c. $16 \mathrm{~mm}$, anticous pair c. $31 \mathrm{~mm}$; anthers purplish, $2 \times 1.5 \mathrm{~mm}$, pollen grey becoming ochre; staminode $1.5 \mathrm{~mm}$. Disc c. $2 \times 3.5 \mathrm{~mm}$, lobes indistinct. Stipe c. $15 \mathrm{~mm}$, with occasional small glandular hairs. Ovary with sessile glands. Style c. $8 \mathrm{~mm}$, glandular hairy. Stigma c. $2 \mathrm{~mm}$ diam. Capsule linear, to $29 \times 0.5 \mathrm{~cm}$. Seed $1.1 \mathrm{~mm}$, papillose, hilar appendage c. $7 \mathrm{~mm}$, lacking bubble cells, apical appendage c. $7 \mathrm{~mm}$.

This species, with its trailing, flexuous stems and shallowly lobed calyx detaching easily from the pedicel, is a typical member of sect. Aeschynanthus. The seeds lack the podium of 'bubble cells' at the base of the hilar appendage that was at one time thought to be diagnostic for the section (Clarke, 1883; Burtt \& Woods, 1975), but some other members of the section, including the Bornean A. tricolor Hook. and the Palawan $A$. arctocalyx Mendum, also lack bubble cells. The large bright red corollas, cream in throat and tube and with a gibbosity at the base, are usually associated with tubular calyces; the calyx of A. curvicalyx, to which the epithet refers, is very different. The type was grown from seed; wild-collected cuttings of the same plant are cult. RBGE accession no. 19980281.

Aeschynanthus (sect. Aeschynanthus) madulidii Mendum, sp. nov. Fig. 1F-I.

$\mathrm{Ab}$ omnibus speciebus Aeschynanthi sect. Aeschynanthi grandifloris borneensibus corollae basi haud gibboso differt, et ab A. elmeri Mendum (vide infra) calyce rubropiloso (haud glabro) tubuloso (non paulo infundibulari), tubo corollae intus papilloso (non glabro) et antheris multo minoribus recedit.

Type: Specimen cult. RBGE accession no. 19980282, originating from Philippines,

FIG. 1. Aeschynanthus curvicalyx Mendum. A, habit; B, calyx (split ventrally); C, corolla (split ventrally); D, gynoecium; E, seed; drawn from RBGE cult. 19981826. Aeschynanthus madulidii Mendum. F, habit; G, calyx (split ventrally); H, corolla (split ventrally); I, gynoecium; drawn from RBGE cult. 19980282. 


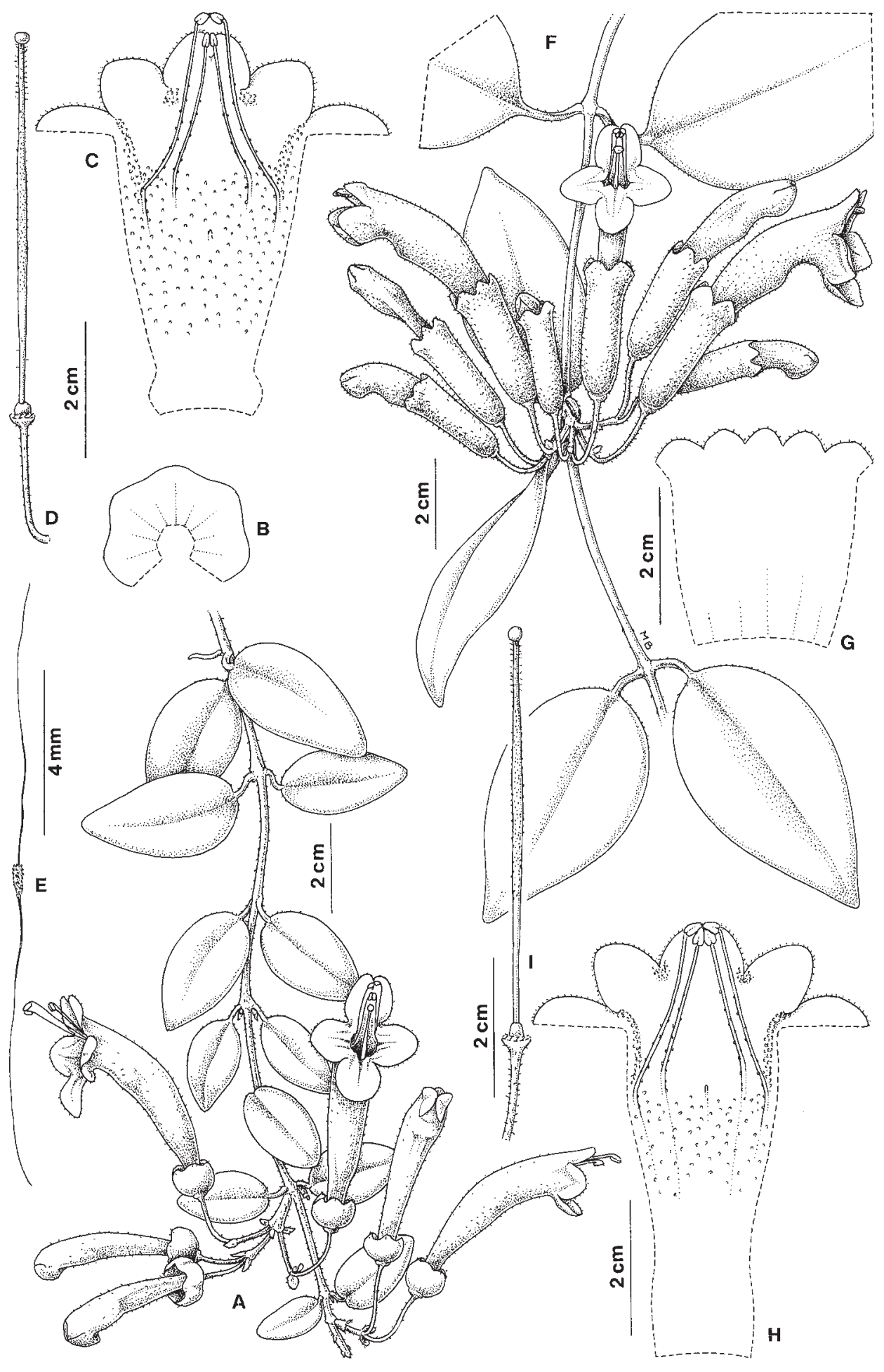


Palawan, Thumb Peak, on path from base camp to peak, alt. 850m, Mendum, Argent, Cronk, Middleton, Wilkie, Fuentes \& Chavez 25512 (holo. PNH, iso. E).

Epiphyte. Stems climbing and rooting from most nodes, becoming pendulous and flexuous, to c. $140 \mathrm{~cm}$, bright green with antrorse white eglandular hairs to $0.2 \mathrm{~mm}$ becoming sparse on older stems; internodes to $5 \times 0.3 \mathrm{~cm}$. Leaves opposite, hard and thick, mid-green above and paler below, minutely white hairy on margins and midvein below especially near base; blade ovate, $4.5-8 \times 2.6-4.1 \mathrm{~cm}$, margins entire, apex acute, tip blunt, base rounded, mid-vein impressed above and prominent below, other veins faintly visible; petioles $9-15 \mathrm{~mm}$, sparsely white hairy. Inflorescences axillary or pseudoterminal on pendulous stems, 2-several-flowered. Peduncles several on short spurs, $3-4 \mathrm{~mm}$, sparsely white hairy, each bearing one or two flowers. Bracts c. $1 \mathrm{~mm}$, linear, hairy. Bracteoles $1.5-5 \mathrm{~mm}$, rounded, sparsely white hairy, caducous. Pedicel to $12 \mathrm{~mm}$, green with pale red eglandular hairs. Calyx with abscission layer at base; dull pale crimson with red eglandular hairs, $2.9-3.3 \mathrm{~cm}$ long, tubular with c. $3 \mathrm{~mm}$ bluntly triangular somewhat irregular lobes, the dorsal lobe the smallest. Corolla tubular, arcuate, $6.2-6.7 \mathrm{~cm}$, straight for basal $1 / 4$ then flaring gradually to throat, three lower lobes spreading; externally bright red, internally cream on floor of throat and tube with red lobes, lower three cream at base and with a red line; upper lobes c. $9 \times 8 \mathrm{~mm}$ (central sinus c. $4 \mathrm{~mm}$ ), rounded oblong, lateral lobes c. $10 \times 9 \mathrm{~mm}$, bluntly triangular, lower lobe c. $13 \times 8 \mathrm{~mm}$, rounded oblong, all fringed with tiny glandular hairs; externally with $0.5 \mathrm{~mm}$ red glandular hairs, internally papillose in middle third of tube and with two densely papillose ridges running from lateral/lower lobe junctions to insertion of anticous filaments, and with thickened areas of tissue and occasional hairs at base of upper/lateral lobe sinuses. Stamens 4 , inserted about $3 / 4$ way up tube and not exserted; filaments cream flushed purple apically, coarsely papillose, posticous pair c. $18 \mathrm{~mm}$, anticous pair c. $26 \mathrm{~mm}$; anthers c. $2.5 \times 1.5 \mathrm{~mm}$, pollen purplish-grey; staminode $1 \mathrm{~mm}$. Disc c. $2 \times 3.5 \mathrm{~mm}$, lobes indistinct. Stipe c. $15 \mathrm{~mm}$, glabrous. Ovary with sessile glands. Style c. $9 \mathrm{~mm}$, glandular hairy, all pale green. Stigma c. $3 \mathrm{~mm}$ diam., cream. Capsule linear to $27 \times 0.5 \mathrm{~cm}$. Seed c. $1 \mathrm{~mm}$, very papillose; hilar appendage c.9mm, lacking bubble cells; apical appendage c. $8 \mathrm{~mm}$.

Again this species is typical for the section, but differs from the large flowered Bornean members with tubular calyces in that it lacks the pronounced gibbosity at the base of the corolla seen in the latter.

Aeschynanthus madulidii is named in honour of Dr Domingo Madulid, head of the Division of Botany, the National Museum, Manila, who has been of much help in facilitating our fieldwork.

The Philippine Trichosporum grandiflorum Elmer, from Mindanao, is similar to $A$. madulidii but differs in its glabrous slightly flared calyx with larger lobes, a lack of papillae on the floor of the corolla tube and much larger anthers. The transfer of 
this species to Aeschynanthus requires a replacement name because A. grandiflorus (D. Don) Spreng. exists already as a synonym of $A$. parasiticus (Roxb.) Wall. The necessary new name is:

Aeschynanthus (sect. Aeschynanthus) elmeri Mendum, nom. nov.

Syn.: Trichosporum grandiflorum Elmer, Leafl. Philipp. Bot. 7: 2667 (1915); non D. Don 1822.

Henckelia corrugata Mendum, sp. nov. Fig. 2A-F.

Aff. H. woodii (Merr.) Weber \& Burtt quae folia minora pilosiora et inflorescentias uniflores habet species nova foliis valde corrugatis inaequaliter serratis, inflorescentiis plurifloras differt. A $H$. crenata (Baker) B. L. Burtt (borneensis) foliis corrugatis (haud laevibus vel paullo bullatis) facile distinguitur.

Type: Specimen cult. RBGE accession no. 19981788, originating from Philippines, Palawan, side of ravine above Camp 3 towards Cleopatra's Needle, alt. 940m, 22 i 1998, Mendum, Argent, Cronk, Middleton, Wilkie, Fuentes \& Chavez 25558 (holo. $\mathrm{PNH}$, iso. E).

Upright herb. Stems to $80 \mathrm{~cm}$, leafless and woody in lower part, brown hairy in leafy part, sometimes branching near base. Leaves opposite, strongly corrugated, crowded towards apex of stem, to $21.5 \times 4.1 \mathrm{~cm}$, linear-lanceolate, apex acute, base rounded, margins irregularly serrate, bright green above and paler with prominent reddish mid-vein below, with brown antrorse hairs along mid-vein above and below, along lateral veins below, and dense at leaf base and on $5 \mathrm{~mm}$ petiole (leaves on juvenile plants ovate-lanceolate with petioles to $12 \mathrm{~mm}$ ). Inflorescences axillary in dichasial cymes, flowers sweetly scented. Rhachis $9.5-11 \mathrm{~cm}$. Calyx divided to base, lobes $3 \times 0.8 \mathrm{~mm}$, linear, pale green, externally with colourless glandular hairs. Corolla $17 \mathrm{~mm}$, dorsoventrally compressed, strongly 2-lipped, floor of lower lip and tube deeply ridged and channelled, tube $8 \mathrm{~mm}$, two upper lobes reflexed, $6 \times 5 \mathrm{~mm}$ (central sinus $3 \mathrm{~mm}$ ) rounded, tips of three lower lobes deflexed; lateral lobes $9 \times 5 \mathrm{~mm}$, rounded oblong, lower lobe $4 \times 5 \mathrm{~mm}$, rounded; corolla externally white with colourless glandular hairs, internally white with pale purple lobes, hairs at base of upper lobes purple, hairs on lower lip to $1.3 \mathrm{~mm}$, pale yellow and very papillose, hairs on floor of tube shorter, smooth and purple. Stamens 2 , filaments $6 \mathrm{~mm}$, white; anthers cohering, ovate, $2.5 \times 1 \mathrm{~mm}$, white; pollen white; paired staminodes unequal, c. $2 \mathrm{~mm}$, third staminode minute. Disc $1.5 \times 2 \mathrm{~mm}$, yellow, glabrous. Ovary green with dense colourless glandular hairs and sessile glands. Style $4.5 \mathrm{~mm}$, white, hairy at base. Stigma c. $1.5 \mathrm{~mm}$, capitate, white, densely and minutely glandular hairy. Capsule linear, straight, $18 \times 1.5 \mathrm{~mm}$. Seed $0.4 \mathrm{~mm}$, ovate, somewhat flattened laterally.

The genus Henckelia Spreng., recently re-established by Weber \& Burtt (1997), is a primarily Sundaland genus of some 180 species, most of which were previously considered to be in Didymocarpus. The only other known Philippine Henckelia, $H$. woodii (Merr.) Weber \& Burtt, is also from Palawan. It is described as having pilose 


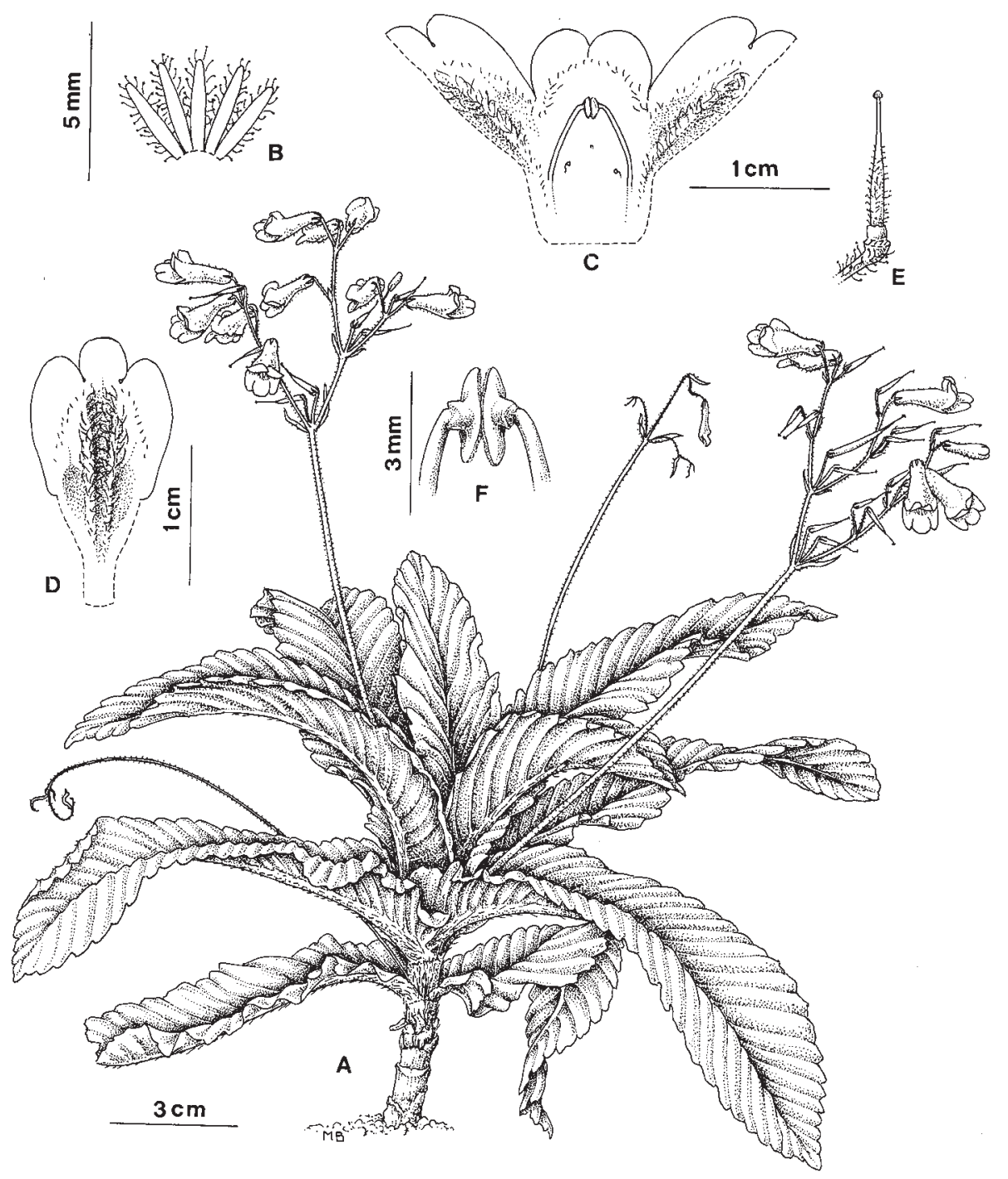

FIG. 2. Henckelia corrugata Mendum. A, habit; B, calyx (split ventrally); C, corolla (split ventrally); D, lower lip; E, gynoecium: $\mathrm{F}$, anthers showing attachment to filaments; drawn from RBGE cult. 19981788.

leaves to $14 \mathrm{~cm}$ and inflorescences bearing single $3 \mathrm{~cm}$ flowers (Merrill, 1925). The Bornean H. crenata (Baker) B. L. Burtt (syn. Didymocarpus multinervius Merr.) appears similar to $H$. corrugata, another indication of the island's Bornean affinities (Weber \& Burtt, 1997), but the leaves are described as being smooth or slightly bullate (Merrill, 1923a). Henckelia corrugata is known only from the type and was grown from leaf cuttings; the epithet refers to the ribbed leaf surface. The sterile 
wild-collected specimen, 'Herb to $80 \mathrm{~cm}$. Rootstock woody. Leaves in top third only.', is a unicate in $\mathrm{PNH}$.

\section{ACKNOWLeDGements}

Thanks are due to Dr R. R. Mill for the Latin diagnoses, to Mr B. L. Burtt for helpful discussion, and to the horticultural staff at RBGE, especially S. Scott and A. Fowler, for their skill and interest. Thanks are also due to the staff of the Philippine National Herbarium, and to our guides in Palawan.

\section{REFERENCES}

Atkins, H. \& Cronk, Q. C. B. (2001). The genus Cyrtandra (Gesneriaceae) in Palawan, Philippines. Edinb. J. Bot. 58 (3): 443-458.

Atrins, H., Preston, J. \& Cronk, Q. C. B. (2001). A molecular test of Huxley's line: Cyrtandra (Gesneriaceae) in Borneo and the Philippines. Biol. J. Linn. Soc. 72: $143-159$.

Burtt, B. L. \& Woods, P. J. B. (1975). Studies in the Gesneriaceae of the Old World XXXIX. Towards a revision of Aeschynanthus. Notes Roy. Bot. Gard. Edinburgh 33: $471-489$

Clarke, C. B. (1883). Cyrtandreae. In: De Candolle, A. \& De Candolle, C., Monographiae Phanerogamarum, Vol. 5 (1), pp. 1-303. Paris: Sumptibus G. Masson.

Elmer, A. D. E. (1915). Trichosporum grandiflorum Elmer. Leafl. Philipp. Bot. 7: 2667. Merrill, E. D. (1923a). Didymocarpus multinervius Merr. J. As. Soc. Mal. I: 32.

Merrill, E. D. (1923b). An Enumeration of Philippine Flowering Plants, Vol. 4. Manila: Bureau of Science.

Merrill, E. D. (1925). Didymocarpus woodii Merrill. Philipp. J. Sci. 26: 489.

Weber, A. \& Burtt, B. L. (1997). Remodelling of Didymocarpus and associated genera (Gesneriaceae). Beitr. Biol. Pflanzen 70: 293-363.

Received 16 October 2000; accepted 20 October 2000 